\title{
The Intergenerational Dimension of Traditional Practices Used by Mother in Infant Care
}

\author{
Annelerin Bebek Bakımında Kullandıkları Geleneksel Uygulamaların \\ Kuşaklararası Boyutu
}

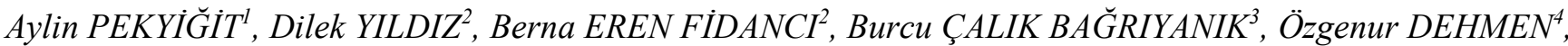 \\ Tuğba KOÇAK $K^{5}$ Sema ALTINTAŞ
}

\begin{abstract}
Objective: The cultural values of society affect the living and health conditions of people. People born in close years have similar characteristics in terms of view of life. This situation reveals the intergenerational difference. Our study was carried out to determine and compare the traditional practices used by Baby Boomer, X, Y and Z Generation mothers in baby care. Methods: This study is a cross-sectional, descriptive and comparative study, and was conducted between 10th of April-10th of July 2018 with a total of 273 mothers who volunteered to participate in the research that applied to the obstetrics clinics of a public hospital. Data were collected through face-to-face interviews. Ethical Committee and related consents were taken. IBM SPSS Statistics 21 package program was used to evaluate the data. Results: In the study, $65.93 \%$ of the mothers who participated in the study were from Generation Y. There is a significant difference in terms of waiting for the call to prayer sound after the birth, milking the first milk and giving the first sugary water to the baby, burying the umbilical cord in a place that has meaning after the fall (mosque, school, etc.), applying salt to the sweaty areas ( $\mathrm{p}<0.05$ ). There was no significant difference between generations in terms of other applications. Conclusion: In our study, traditional practices that are harmless to the baby are used as well as traditional practices that are harmful. In the intergenerational comparison, Baby Boomer Generation has mostly used harmful practices.
\end{abstract}

Key words: Generation, baby care, traditional practices

\section{ÖZET}

Amaç: Toplumun kültürel değerleri, insanların yaşam ve sağlık koşullarını etkilemektedir. Birbirine yakın yıllarda doğan insanlar, hayata bakış açısından benzer özellikler taşımaktadırlar. Bu durum kuşaklararası farklıı̆̆ ortaya çıkartmaktadır. Araştırmamız, Bebek Patlaması, X, Y ve Z Kuşağı annelerinin bebek bakımında kullandıkları geleneksel uygulamaları belirlemek ve karşılaştırmak amacıyla yapılmıştır. Yöntem: Bu araştırma kesitsel, tanımlayıcı ve karşılaştırmalı bir araştırma olup 10.04.2018-10.07.2018 tarihleri arasında, bir devlet hastanesinin kadın doğum polikliniklerine başvuran, araştırmaya katılmaya gönüllü 273 anne ile yürütülmüştür. Veriler, anket formu aracılığı ile yüz yüze görüşülerek toplanmıştır. Çalışma için etik kurul izni ve gerekli izinler alınmıștır. Verilerin değerlendirilmesinde IBM SPSS Statistics 21 paket programından yararlanılmıștır. Bulgular: Araştırmaya katılan annelerin, \%65,93'ü Y Kuşağı'ndandır. Doğumdan sonra bebeği beslemek için ezan sesinin beklenmesi, ilk sütün sağılıp atılması, bebeğe ilk şekerli suyun verilmesi, göbek bağının düştükten sonra anlamlı bir yere (cami, okul vb.) gömülmesi, çok terleyen bölgelerine tuz sürülmesi açısından önemli bir farklılık vardır $(p<0,05)$. Diğer uygulamalar yönünden kuşaklararasında önemli bir farklılık görülmemiştir. Sonuç: Araştırmamızda bebeğe zararı olmayan geleneksel uygulamaların yansıra zararı olan geleneksel uygulamaların da kullanıldığı saptanmıştır. Kuşaklararası karşılaştırmada zararlı uygulamaları çoğunlukla Bebek Patlaması Kuşağı kullanmıştır.

Anahtar Kelimeler: Kuşaklar, bebek bakımı, geleneksel uygulamalar

Received / Geliş tarihi: 07.05.2020, Accepted / Kabul tarihi: 17.06.2020

${ }^{1}$ Çankırı Karatekin Üniversitesi, Sağlık Bilimleri Fakültesi, Çocuk Sağlığı ve Hastalıkları Hemşireliği Anabilim Dalı

${ }^{2}$ Sağlık Bilimleri Üniversitesi, Gülhane Hemşirelik Fakültesi

${ }^{3}$ Ankara Yıldırım Beyazıt Üniversitesi, Sağlık Hizmetleri Meslek Yüksek Okulu

${ }^{4}$ Hemşire, Ankara/Türkiye

${ }^{5}$ Hemşire, Yozgat/Türkiye

${ }^{6}$ Hemşire, Bilecik/Türkiye

*Address for Correspondence / Yazışma Adresi: Aylin PEKYİ̆̈IT, Çankırı Karatekin Üniversitesi, Sağlık Bilimleri Fakültesi, Çocuk Sağlı̆̆ı ve Hastalıkları Hemşireliği ABD Merkez/Çankırı/TÜRKIYE, E-mail: aylinpekyigit@hotmail.com

Pekyiğit A, Yıldız D, Eren Fidancı B, Çalık Bağrıyanık B, Dehmen Ö, Koçak T, Altıntaş S. Annelerin Bebek Bakımında Kullandıkları Geleneksel Uygulamaların Kuşaklararası Boyutu. TJFMPC, 2020;14(4): 443-451.

DOI: $10.21763 / \mathrm{tjfmpc} .733696$ 


\section{Gİiș}

Kültür, Türk Dil Kurumu (TDK)'na göre “Tarihsel, toplumsal gelişme süreci içinde yaratılan bütün maddi ve manevi değerler ile bunları yaratmada, sonraki nesillere iletmede kullanılan, insanın doğal ve toplumsal çevresine egemenliğinin ölçüsünü gösteren araçların bütünü” olarak tanımlanmaktadır. ${ }^{1}$ Kültürü şekillendiren etmenler arasında gelenek ve göreneklerin önemi büyüktür. ${ }^{2}$ Toplumun kültürel değerleri, gelenekleri, inançları kişilerin yaşam ve sağlık koşullarını etkilemektedir. ${ }^{3}$

Hemen hemen aynı dönemde, aynı zaman aralığında doğan, aynı düşünce ve eylemlere sahip, özellikleri belli bir dönem olayı ile şekillenmiş kişilerin oluşturduğu gruplara kuşak denir. Günümüzde kuşak sınıflandırılması, X, Y, Z, Bebek Patlaması ve Gelenekselciler olarak yapılmaktadır. Birbirine yakın yıllarda doğan insanlar, alg1, beklenti ve hayata bakış açısından benzer özellikler taşımaktadırlar. Bu durum kuşaklararası farklılığg ortaya çıkartmaktadır. ${ }^{4}$

Gelenekselciler (Traditionalists/Veterans); 1922-1945 yılları arasında dünyaya gelen gruplardan oluşmaktadır. ${ }^{4}$ Bulunduğumuz dönemin en yaşlı grubunu oluşturmaktadırlar. ${ }^{5}$ Dünya genelinde yaşanan açlık, kıtlık, savaşlar, ekonomik sorunlar gibi birçok sorunlara tanık olmuşlardır. Geleneksel değerlere sadıktırlar. $\mathrm{Bu}$ nedenle kendi dönemlerinde kullanılan geleneksel bebek bakım yöntemlerini çocuklarına da uygulamış olabileckelri düşünülmektedir. ${ }^{4}$

Bebek Patlaması Kuşağı; 1946-1964 yılları arasında doğan gruplardan oluşmaktadır. Gelenekselci annelerin çocuklarıdır. İkinci Dünya Savaşı'ndan sonra nüfus patlaması yıllarında dünyaya gelenlerin ortak özellikleri ise sadakat duyguları yüksek, kanaatkar, kuralcı olmalarıdır. ${ }^{4}$

X Kuşağ1; 1965-1979 yılları arasında doğan gruplardan oluşmaktadır. ${ }^{4}$ Teknoloji ve yeni bilgiler ile barışık, değişen dünyaya uyum sağlamaya çalışan insanlardır. Bu anlamda gelenekselcilerden ve bebek patlaması kuşağından ayrılmaktadırlar. Ayrıca X kuşağı kadınları, erkekler kadar iş yaşamında aktif olmaya başlamışlardır. Televizyon da bu dönemde yaygınlaştığından bilgi akışı hızlanmıştır. ${ }^{4,6}$

Y Kuşağ1; 1980-1999 yılları arasında doğan gruplardan oluşmaktadır. ${ }^{7}$ Teknolojiyle en erken yaşlarda tanışan ilk kuşak özelliğini taşımaktadırlar. Bilgiye hızlı ulaşabilme imkanları vardır. Değişim için isteklidirler. ${ }^{6,8}$

Z Kuşağı; 2000 ve üzeri yılları arasında doğan gruplardan oluşmaktadır. İnternet kuşağ1 olarak da bilinirler. Özellikleri henüz tanımlanmamıştır. Fakat Y kuşağı gibi teknolojinin tam ortasında dünyaya gelmişlerdir. ${ }^{7}$

İnsanların, sağlığa ilişkin inanç ve uygulamaları, içinde yaşamış olduğu toplum kültürünün bir parçasıdır. Geleneksel uygulamalar adı altında yapılan bu uygulamaların günümüzde halen kullanılmaya devam edildiği birçok çalışma ile ortaya çıkarılmıştır. Dolayısıyla farklı dönemlerde yaşamış, birbirlerinden farklı özelliklere sahip olan kuşakların bir arada yaşaması, sahip olunan kültürel zenginliklerin yanı sıra, iletişim sorunları gibi pek çok çatışmaları beraberinde getirebilmektedir. Özellikle bebeklere uygulanan, kuşaktan kuşağa aktarılan zararlı geleneksel uygulamalar, bebekte hastalıklara, enfeksiyonların gelişmesine, tedavi sürecinin uzamasına, gelecek yaşantısında sekel kalmasina neden olabilmektedir. ${ }^{2,8-12}$ Yapilan araştırmalara göre, kadınların doğum sonu dönemde, yeni doğan ve lohusalığa ilişkin çeşitli geleneksel uygulamaları yaygın olarak sürdürdükleri belirlenmiştir. ${ }^{2,13-16}$ Ailedeki yanlış inançlar ve uygulamalar bebeğe zarar verebilmektedir. ${ }^{15-16}$ Sağlık profesyonelleri farklı kültürel özellikleri olan bireylere ve ailelere bakım vermektedirler. Dolayısıyla toplumun kültürel yapısını bilmesi ve değerlendirmesi, vereceği sağlık bakımının kalitesinde artış sağlayacağı düşünülmektedir.

Sağllk profesyonelleri, birey, aile ve topluma yönelik bakım girişimlerini planlarken ve uygularken toplumun hangi zamana uyumlu yaşadığını bilmesi gerekmektedir. ${ }^{3}$ Gelişen teknoloji ile birlikte, anneler de bebek bakımı konusunda ihtiyaç duydukları bilgilere erişmekte kolaylık yaşamaktadırlar. Buna rağmen aralarında kuşak fark1 olan büyüklerine de danışma gereği duyabilirler. Ülkemizde, sağlığa zararı olmadığ bilinen bebek bakım uygulamalarının (göbek bağını anlamlı bir yere gömmek vb.) yanı sıra bebeğe zarar verebilecek (doğumdan hemen sonra ezan sesi duymadan ilk beslenmesini başlatmamak, tuzlamak vb.) geleneksel uygulamalar da yer almaktadır. Bu tür geleneksel uygulamaların belirlenerek eğitim planlarının yapılması gereklidir. Literatürde, bebek bakımında kullanılan geleneksel inanç ve uygulamaların kuşaklararası karşılaştırmasını içeren bir araştırmaya ulaşılamamıştır.

Bu çalışmadaki amacımız, farklı kuşaklara ait annelerin bebeklerine uyguladıkları geleneksel yöntemleri belirlemek ve karşılaştırmaktır.

\section{YÖNTEM}

Araştırmamız, kesitsel, tanımlayıcı ve karşılaştırmalı bir çalışma olup, 10 Nisan 2018-10 Temmuz 2018 tarihleri arasında tarihleri arasında bir devlet hastanesi kadın doğum polikliniklerinde yapılmıştır. 
Araştırmanın evrenini, 10 Nisan 2018-10 Temmuz 2018 tarihleri arasında, bir devlet hastanesinin kadın doğum polikliniklerine başvuran anneler, örneklemini ise doğum yılı 1946-1999 yılları arasında olan, en az bir çocuk sahibi, iletişim sorunu olmayan, Türk toplum kültürü yapısına sahip, araştırmaya katılmaya gönüllü 273 anneden oluşturmaktadır.

\section{Veri Toplama Aracı}

Veri toplamada, araştırmacılar tarafından literatür doğrultusunda hazırlanan ${ }^{2,}$ 9-13 42 sorudan oluşan veri toplama formu kullanılmıştır. Veri toplama formu iki bölümden oluşmaktadır. Birinci bölümde, anneye ait sosyodemografik özellikler (6 soru) ve doğumuna ait bilgiler (6 soru) yer almaktadır. İkinci bölümde ise, bebek bakımına yönelik sık kullanılan geleneksel yöntemlere ilişkin sorular (30 soru) yer almaktadır. Annelerin bebek bakımında sık kullandıkları geleneksel uygulamalar kısmı üçlü likert tipte "Evet", "Hayır" ve "Fikrim yok" şeklinde hazırlanmıştır. Anket formu araştırmacılar tarafından yüz yüze görüşülerek yaklaşık 10 dakikada doldurulmuştur.

\section{Etil İlkeler}

Çalışmanın yapılabilmesi için, T.C. Çankırı Karatekin Üniversitesi Etik Kurulu'ndan etik kurul onayı alınmıştır (Onay Tarihi: 21.03.2018 ve Sayı: 25). Ayrıca Çankırı İl Sağlık Müdürlüğü'nden (Onay Tarihi: 09.04.2018 ve Sayı: 39991120-773.9-E.344) kurum izni ve katılımcıların bilgilendirilmiş gönüllü oluru alınmıştır.

\section{İstatistiksel Analiz}

Çalışmadan elde edilen veriler değerlendirilirken, IBM SPSS Statistics 21 (Statistical Package for
Social Sciences) paket programı kullanılmıştır. Elde edilen verilerin normal dağılıma uygunluk göstermediği Shapiro Wilk testi ile belirlenmiștir. Kategorik veriler sıklık (n) ve yüzde (\%) olarak belirtilmiştir. Normal dağılıma uygunluk göstermeyen dört gruptan oluşan kuşakların karşılaştırılmasında Kruskal Wallis $\mathrm{H}$ testi kullanılmıştır. Oluşturulan çapraz tabloların analizinde Monte Carlo Ki-kare testi kullanılmıştır. İstatistiksel olarak önemlilik düzeyi $\mathrm{p}<0.05$ olarak kabul edilmiştir.

\section{BULGULAR}

Araştırmaya katılan annelerin \%65,93'ü Y Kuşağ1 anneleridir (Tablo 1). Y Kuşağı'nın \%86,66's1 ortaokul mezunu, \%63,33'ü çekirdek aile yapısına sahip, \%62.77'si geliri giderine denk annelerdir. Bebek Patlaması Kuşağı'ndaki annelerin \%33,34'ü evde doğum yapmış olup \%80,00'1 ikiden fazla çocuk sahibidir. Z Kuşağı'ndaki annelerin \%86,66's1 emzirmiștir. X Kuşağı'ndaki anneler bebek bakımı ile ilgili bilgiyi \%58,33 oranında aile büyüklerinden almışlardır (Tablo 2).

\begin{tabular}{|l|l|l|}
\hline \multicolumn{3}{|l|}{ Tablo 1. Annelerin tanıtıcı özellikleri } \\
\hline DEĞiŞKENLER & n & \% \\
\hline Annelerin Doğum Yılları Aralı̆̆ \\
\hline $1946-1964$ (Bebek Patlaması) & 30 & 10,99 \\
\hline $1965-1979(\mathrm{X})$ & 48 & 17,59 \\
\hline $1980-1999(Y)$ & 180 & $\mathbf{6 5 , 9 3}$ \\
\hline 2000 ve üzeri (Z) & 15 & 5,49 \\
\hline Toplam & $\mathbf{2 7 3}$ & $\mathbf{1 0 0}$ \\
\hline
\end{tabular}

\begin{tabular}{|c|c|c|c|c|c|}
\hline DEĞİŞKENLER & $\begin{array}{l}\text { Bebek } \\
\text { Patlaması } \\
(\%) \\
\end{array}$ & $\begin{array}{l}\text { X } \\
\text { Kuşağı } \\
(\%)\end{array}$ & $\begin{array}{l}\text { Y } \\
\text { Kuşağı } \\
(\%)\end{array}$ & $\begin{array}{l}\text { Z } \\
\text { Kuşağı } \\
(\%)\end{array}$ & $\begin{array}{l}\text { Kikare* } \\
\text { p }\end{array}$ \\
\hline \multicolumn{6}{|c|}{ Annelerin Eğitim Durumları } \\
\hline Okur-Yazar Değil & 36,66 & 6,25 & 3,34 & 0,00 & \multirow[t]{5}{*}{$<0,001$} \\
\hline İlkokul & 46,66 & 50,00 & 21,11 & 13,34 & \\
\hline Ortaokul & 3,34 & 10,42 & 28,33 & 86,66 & \\
\hline Lise & 10,00 & 20,83 & 25,00 & 0,00 & \\
\hline Üniversite & 3,34 & 12,50 & 22,22 & 0,00 & \\
\hline \multicolumn{6}{|l|}{ Aile Tipi } \\
\hline Çekirdek & 40,00 & 43,75 & 63,34 & 60,00 & \multirow[t]{3}{*}{0,080} \\
\hline Geniş & 60,00 & 54,16 & 35,00 & 40,00 & \\
\hline Parçalanmış & 0,00 & 2,09 & 1,66 & 0,00 & \\
\hline \multicolumn{6}{|l|}{ Gelir Durumu } \\
\hline Gelir giderden fazla & 13,34 & 18,75 & 8,88 & 6,67 & \multirow[t]{3}{*}{0,165} \\
\hline Gelir gidere eşit & 50,00 & 41,67 & 62,78 & 66,67 & \\
\hline Gelir giderden az & 36,66 & 39,58 & 28,34 & 26,66 & \\
\hline
\end{tabular}




\begin{tabular}{|c|c|c|c|c|c|}
\hline \multicolumn{6}{|l|}{ Yaşanılan Yer } \\
\hline İl & 40,00 & 47,91 & 57,78 & 93,34 & \multirow{3}{*}{$\mathbf{0 , 0 3 7}$} \\
\hline İlçe/Kasaba & 46,66 & 39,59 & 33,88 & 6,66 & \\
\hline Köy & 13,34 & 12,50 & 8,34 & 0,00 & \\
\hline \multicolumn{6}{|l|}{ Çalıșma Durumu } \\
\hline Çalışıyor & 3,34 & 16,66 & 26,66 & 53,34 & \multirow[t]{2}{*}{0,001} \\
\hline Çalışmıyor & 96,66 & 83,34 & 73,34 & 46,66 & \\
\hline \multicolumn{6}{|l|}{ Sosyal Güvence } \\
\hline Var & 83,34 & 83,34 & 84,44 & 100,00 & \multirow{2}{*}{$\mathbf{0 , 0 1 7}$} \\
\hline Yok & 16,66 & 16,66 & 5,56 & 0,00 & \\
\hline \multicolumn{6}{|l|}{ Doğum Yapılan Yer } \\
\hline Sağlık Kuruluşu & 30,00 & 83,34 & 95,00 & 100,00 & \multirow[t]{3}{*}{$<0,001$} \\
\hline Ev & 33,34 & 6,25 & 1,11 & 0,00 & \\
\hline En az bir doğum evde & 36,66 & 10,41 & 3,89 & 0,00 & \\
\hline \multicolumn{6}{|l|}{ Doğum Sayısı } \\
\hline 1 & 3,34 & 14,58 & 33,34 & 46,66 & \multirow[t]{4}{*}{$<0,001$} \\
\hline 2 & 16,66 & 41,67 & 38,33 & 53,34 & \\
\hline 3 & 40,00 & 31,25 & 21,11 & 0,00 & \\
\hline 4 ve üzeri & 40,00 & 12,50 & 7,22 & 0,00 & \\
\hline \multicolumn{6}{|l|}{ Emzirme Durumu } \\
\hline Evet & 90,00 & 95,84 & 91,66 & 86,66 & \multirow[t]{2}{*}{0,633} \\
\hline Hayır & 10,00 & 4,16 & 8,34 & 13,34 & \\
\hline \multicolumn{6}{|c|}{ Bebek Bakımı ile ilgili İlk Bilgi Alma Kaynağı } \\
\hline Doktor & 16,66 & 20,83 & 31,70 & 26,67 & \multirow{7}{*}{$\mathbf{0 , 0 2 3}$} \\
\hline Hemşire & 10,00 & 10,41 & 15,00 & 13,34 & \\
\hline Ebe & 16,66 & 4,16 & 8,88 & 6,67 & \\
\hline Aile büyükleri & 40,00 & $\mathbf{5 8 , 3 4}$ & 37,77 & 26,66 & \\
\hline Kitaplar & 3,34 & 2,09 & 2,77 & 0,00 & \\
\hline Kendisi & 13,34 & 4,17 & 2,77 & 26,66 & \\
\hline İnternet & 0,00 & 0,00 & 1,11 & 0,00 & \\
\hline \multicolumn{6}{|c|}{ Bebek Rahatsızlandığında İlk Başvurulan Yer } \\
\hline Aile Sağlı̆̆1 Merkezi & 23,33 & 27,08 & 23,34 & 20,00 & \multirow[t]{6}{*}{0,002} \\
\hline Hastane & 36,66 & 53,25 & 68,34 & $\mathbf{8 0 , 0 0}$ & \\
\hline Aile büyükleri & 26,66 & 10,09 & 3,89 & 0,00 & \\
\hline Arkadaş, yakın vb. & 10,00 & 6,25 & 2,77 & 0,00 & \\
\hline İnternet & 3,35 & $\mathbf{3 , 3 3}$ & 1,66 & 0,00 & \\
\hline Toplam & 100,00 & 100,00 & 100,00 & 100,00 & \\
\hline
\end{tabular}

* Monte Carlo Ki-kare testi

Kuşaklara göre, bebeğin ilk beslenme zamanı incelendiğinde, doğumdan sonra bebeği beslemek için ezan sesinin beklenmesi $(\mathrm{p}<0,001)$, ilk sütün sağılıp atılması $(p=0,045)$ ve bebeğe ilk şekerli suyun verilmesi $(\mathrm{p}=0,016)$ açısından önemli bir farklılık görülmüştür. Bebeği beslemek için ezan sesinin beklenmesi ve bebeğe ilk şekerli suyun verilmesi en fazla Bebek Patlaması Kuşağı'nda iken, ilk sütün sağılıp atılması X Kuşağında daha fazla görülmektedir. Kuşaklara göre göbek bakımında kullanılan geleneksel uygulamalar arasında önemli bir farklılık bulunamamıştır ( $p>0,05)$. Fakat göbeğin düştükten sonra anlamlı bir yere (cami, okul vb.) gömülmesi açısından önemli bir farklılık tespit edilmiş ( $\mathrm{p}=0,039)$, en çok Bebek Patlaması Kuşağında görülmüsşür. Bebeğin ilk banyosu sırasında yapılan uygulamalar incelendiğinde, ilk yıkama zamanı ve banyo suyuna tuz eklenmesi açısından önemli bir farklılık bulunmamıştır( $\mathrm{p}>0,05)$. Fakat kırklama yapılması $(p=0,007)$ ve çok terleyen bölgelerine tuz sürülmesi $(p<0,001)$ yönünden önemli bir farkl1lık tespit edilmiştir. Bebek Patlaması Kuşağı diğer kuşaklara göre daha fazla kırklama yapmış ve bebeklerine tuz sürmüşlerdir (Tablo 3). 


\begin{tabular}{|c|c|c|c|c|c|}
\hline Kuşaklar & $\begin{array}{l}\text { Bebek } \\
\text { Patlaması }\end{array}$ & $\begin{array}{l}\text { X } \\
\text { Kuşağı }\end{array}$ & $\begin{array}{l}\text { Y } \\
\text { Kuşağı }\end{array}$ & $\begin{array}{l}\text { Z } \\
\text { Kuşağı }\end{array}$ & \multirow[t]{2}{*}{$\begin{array}{l}\text { Kikare* } \\
\text { p }\end{array}$} \\
\hline Uygulamalar (\%) & Evet & Evet & Evet & Evet & \\
\hline \multicolumn{6}{|l|}{ BEBEĞIN İLK BESLENME ZAMANI } \\
\hline $\begin{array}{l}\text { Doğumdan sonra bebeği beslemek için ezan sesi } \\
\text { beklenir. }\end{array}$ & 53,33 & 25,00 & 10,00 & 13,00 & $<0,001$ \\
\hline İlk süt sağılıp atılır. & 6,66 & 22,91 & 7,22 & 13,33 & 0,045 \\
\hline Bebeğe ilk inek sütü verilir. & 33,33 & 2,08 & 5,00 & 6,66 & 0,882 \\
\hline Bebeğe ilk şekerli su verilir. & 43,33 & 25,00 & 16,11 & 13,33 & 0,016 \\
\hline \multicolumn{6}{|l|}{ BEBEĞIN GÖBEK BAKIMI ve SAKLANMASI } \\
\hline Zeytinyağı sürülür. & 53,33 & 22,91 & 36,66 & 40,00 & 0,060 \\
\hline Kahve tozu sürülür. & 3,33 & 0,00 & 5,00 & 0,00 & 0,087 \\
\hline Demir para koyulur. & 10,00 & 14,58 & 16,11 & 6,66 & 0,100 \\
\hline Pudra sürülür. & 40,00 & 27,08 & 24,44 & 40,00 & 0,406 \\
\hline Alkol sürülür. & 6,66 & 12,50 & 10,55 & 6,66 & 0,529 \\
\hline Tentürdiyot (Batikon) sürülür. & 23,33 & 43,75 & 34,44 & 53,33 & 0,197 \\
\hline $\begin{array}{l}\text { Düşstükten sonra anlamı olan bir yere (cami, okul vb.) } \\
\text { gömülür. }\end{array}$ & 86,66 & 68,75 & 61,11 & 46,66 & 0,039 \\
\hline \multicolumn{6}{|l|}{ BEBEĞİN İLK BANYOSU } \\
\hline Göbek bağı düşmeden önce yıkanır. & 26,66 & 35,41 & 39,44 & 33,33 & 0,616 \\
\hline Göbek bağ1 düştükten sonra yıkanır. & 66,66 & 66,66 & 60,55 & 80,00 & 0,423 \\
\hline Kırkı çıktıktan sonra yıkanır. & 36,66 & 35,41 & 27,77 & 40,00 & 0,850 \\
\hline Kırklama yapılır. & 83,33 & 81,25 & 76,11 & 46,66 & 0,007 \\
\hline Banyo suyuna tuz eklenir. & 53,33 & 43,75 & 31,11 & 13,33 & 0,072 \\
\hline Çok terleyen bölgelere tuz sürülür. & 50,00 & 47,91 & 25,55 & 33,33 & $<0,001$ \\
\hline \multicolumn{6}{|l|}{ GENEL BAKIM UYGULAMALARI } \\
\hline Kırkı çıktıktan sonra tırnakları kesilir. & 70,00 & 54,16 & 41,11 & 46,66 & 0,002 \\
\hline $\begin{array}{l}\text { Nazardan koruyucu uygulamalara başvurulur (mavi } \\
\text { boncuk, dua vb.). }\end{array}$ & 70,00 & 70,83 & 60,55 & 40,00 & 0,129 \\
\hline Kırk günlük olana kadar adetli kadına gösterilmez. & 66,66 & 41,66 & 33,88 & 46,66 & 0,057 \\
\hline Kundaklanır. & 90,00 & 79,02 & 76,11 & 80,00 & 0,765 \\
\hline $\begin{array}{l}\text { Sarılı̆̆ı önlemek için sarı renkler giydirilir, sar1 } \\
\text { tülbent kullanılır. }\end{array}$ & 60,00 & 43,75 & 48,33 & 80,00 & 0,207 \\
\hline $\begin{array}{l}\text { Bebeğin ağzına, pamukçuk olduğunda, saç, şeker, } \\
\text { annenin saçı vb. uygulanır. }\end{array}$ & 70,00 & 64,58 & 55,00 & 73,33 & 0,315 \\
\hline $\begin{array}{l}\text { Bebeğin gözlerine sürme çekme, süt sürme vb. } \\
\text { yöntemler uygulanır. }\end{array}$ & 96,66 & 54,16 & 48,88 & 33,33 & $<0,001$ \\
\hline Pişiğe pudra uygulanır. & 60,00 & 47,91 & 43,88 & 46,66 & 0,556 \\
\hline Pişiğe zeytinyağı uygulanır. & 40,00 & 16,66 & 33,88 & 20,00 & $\mathbf{0 , 0 0 1}$ \\
\hline Kabız bebeğe zeytinyağ 1 içirilir. & 73,33 & 66,66 & 58,88 & 60,00 & 0,655 \\
\hline Kabız bebeğin anüsüne sabun sürülür. & 56,66 & 37,50 & 25,00 & 40,00 & 0,014 \\
\hline Gaz sancısı varsa rezene veya anason çayı verilir. & 56,66 & 43,75 & 44,44 & 53,33 & 0,547 \\
\hline Ağlayan bebek alışmaması için kucağa alınmaz. & 60,00 & 56,25 & 40,55 & 46,66 & 0,333 \\
\hline
\end{tabular}

*Monte Carlo Ki-kare testi

\section{TARTIŞMA}

Bebek Patlaması, X, Y ve Z Kuşağ 1 annelerinin bebek bakımında kullandıkları geleneksel uygulamaları belirlemek amaciyla yapilan araştırmamızın tartışma bölümü 7 başlıktan oluşmaktadır.

Bebeğin Beslenmesi ile ilgili Geleneksel Uygulamalar; Dünya Sağlık Örgütü’nün önerisi ile TC Sağlık Bakanlığı tarafindan yürütülen Anne 
Sütünün Teşviki ve Bebek Dostu Sağlık Kuruluşları Programı'na göre "Bebeklerin doğumdan hemen sonra ilk bir saat içinde emzirmeye başlatılması, ilk 6 ay sadece anne sütü verilmesi ve 6 . aydan sonra uygun besinlerle beraber emzirmenin 2 yaş ve ötesine kadar devam ettirilmesi" amaçlanmıştır. ${ }^{17}$ Doğum sonrası ilk 5 günde salgılanan süte kolostrum denir. Sekretuvar immunglobulin A, laktoferrin gibi immünolojik faktörleri içerdiği gibi bebeğin gerekli besin kaynaklarını da karşılamak için yeterlidir. ${ }^{18}$ Bebeğin bu mucizeden yararlanması için doğum sonrası ilk yarım saat içinde emzirmenin başlatılması önemlidir. ${ }^{19}$ Ülkemizde, Türkiye Nüfus ve Sağlık Araştırmaları (TNSA) 2018 Raporu'na göre ilk bir saatte emzirilmeye başlanma oranı $\% 71$ 'dir. Annelerin eğitim düzeyi, kentsel bölgede yaşama oranı, doğumda sağlı profesyonellerinden yardım alma oranı arttıç̧a ilk bir saatte emzirme olasılığı da yükselmektedir ${ }^{20}$.

Çalışmamızda, kuşaklara göre bebeğin ilk beslenme zamanı incelendiğinde, doğumdan sonra bebeği beslemek için ezan sesinin beklenmesi, ilk sütün sağılıp atılması ve bebeğe ilk şekerli suyun verilmesi açısından önemli bir farklılık bulunmuştur $(p<0.05)$. Bebeği beslemek için ezan sesinin beklenmesi, bebeğe ilk şekerli suyun verilmesi en fazla Bebek Patlaması Kuşağı'nda iken ilk sütün sağılıp atılması $X \quad$ Kuşağı'nda görülmektedir. TNSA (2018) Raporu'na göre, ülkemizde yıllara göre bebeklerin ilk beslenmeye başlama zamanında olumlu gelişmeler mevcuttur. ${ }^{20}$ Fakat halen çeşitli inançlarla, beslenme zamanında gecikmeler ve uygun olmayan gidaların yeni doğana verilmesi birçok araştırma ile kanıtlanmıştır. Yapılan bazı araştırmalarda, ezan okunduktan sonra bebeklerini emzirdiği, kolostrumu sağıp attığ $1,2,21$ bebeğe ilk olarak inek sütü, şekerli su, ${ }^{21-22}$ zemzem ${ }^{22}$ verdiği belirlenmiştir.

Araştırmamızda, emziren annelerden \%95,84'ü X Kuşağ1, \%86,66's1 ise Z Kuşağ1 anneleridir. TNSA 2018 Raporu'na göre, ülkemizde annelerin \%98'i bebeğini bir süre emzirmekle birlikte yıllar içerisinde bir düşüş göstermektedir. Son beş y1l içindeki tüm doğumların \%52'si sezaryen ile yapılmıştır. ${ }^{20}$ Ülkemizde eğitim seviyesinin yıllara göre artmasına rağmen, halen ilk bir saat içerisinde anne sütü ile beslenme yerine formül mamalar tercih edilmektedir. Bunun nedenlerinden biri de artan sezaryen doğumlar sonrası anne-bebek iletişiminin ve emme refleksinin en aktif olduğu ilk yarım saatte bebeğin emzirilmesinin gecikmesi olabileceği düşünülmektedir.

Bebeğin Bakımı/Sağlık Sorunu ile ilgili Bilgi Alma Kaynakları; Annelerin, bebek bakımına yönelik bilgi yetersizlikleri, yanlış inanç ve uygulamaları bebeğin yaşamını tehlikeye atacak nitelikte olabilir. Araştırmamızda en fazla aile büyüklerine danışan grup \%58,4 ile X Kuşağı anneleridir. Yapılan diğer çalışmalar, araştırmamızla benzerlik göstermekte olup yaş ortalaması 32 olan annelerin en fazla bilgi aldığ 1 kaynak $\% 58,1$ oranında aile büyükleridir. ${ }^{9}$

\section{Bebeğin Genel Bakımı ile ilgili Geleneksel Uygulamalar}

Banyo, Tuzlama, Kırklama; Yeni doğan, doğumdan sonra en az 6 saat yıkanmamalıdır. Yalnızca vücuduna silme banyo yaptırılabilir. ${ }^{23}$ Tuzlama, bebek büyüdüğünde terinin pis kokmaması amaciyla, banyo suyuna tuz eklenmesi ya da çok terleyen bölgelerine tuz sürülmesi şeklinde uygulanmaktadır. Bu geleneksel uygulama yeni doğan bebeğin savunmasız ve hassas olan cildine zarar verdiği için aynı zamanda ağrıya neden olmaktadır. $^{2}$ Kırklama ise bebeğin doğum sonrası yirminci ve kırkıncı gününde özel olarak banyo yaptırılmasıdır. Kırklama yapılırken, banyo suyuna, çeşitli nedenlerle en çok altın, gümüş alyans ya da kırk taş koymaktadırlar. Dolayısıyla enfeksiyon riski açısından zararlı bir uygulamadır.

\section{Araştırmamızda, kuşaklara göre bebeğin ilk banyosu sirasinda yapilan uygulamalar} incelendiğinde, bebeğin ilk yıkama zamanı ve banyo suyuna tuz eklenmesi açısından önemli bir farklılık bulunamamıştır $(p>0,05)$. Fakat kırklama yapılması ve çok terleyen bölgelerine tuz sürülmesi yönünden önemli bir farklılık tespit edilmiştir $(\mathrm{p}<0.05)$. Bebek Patlaması Kuşağı diğer kuşaklara göre daha fazla kırklama yapmış ve bebeklerine tuz sürmüşlerdir. Yapılan birçok çalışmada annelerin bebeklerini kokmaması amaciyla tuzladıkları, 2, 9, 13,21-22 kırklama ritüelini uyguladıkları ${ }^{2,13,21}$ ve kırk günlük olana kadar yıkamadıkları ${ }^{2}$ belirlenmiştir.

Göbek Bakımı; Göbek kordonu, intrauterin dönemde bebek ve plasentayı birbirine bağlayan kan damarları ve bağ dokusundan oluşan bir yapıdır. ${ }^{24}$ Göbek güdüğünde bulunan nekrotik wharton jeli enfeksiyonlara yatkındır. ${ }^{25}$ Enfeksiyonların vücuda girişi için bir kapı özelliği taşımaktadır. ${ }^{26}$ Dünya Sağlık Örgütü (DSÖ)'ne göre gelişmiş ülkelerde kuru bakım önerilirken, neonatal ölüm hızının binde 30'dan fazla olduğu gelişmekte olan ve geleneksel uygulamaların (inek gübresi gibi) yoğun olarak kullanıldığı ülkelerde klorheksidinli bakımı önermektedir. ${ }^{27}$ Türkiye Sağlık İstatistikleri Y1llı̆̆ 2018 verilerine göre, ülkemizde neonatal ölüm hızı binde 6 'dır. ${ }^{28}$ Ülkemizde neonatal ölüm hızı binde 30'un altında olmasına rağmen yeni doğanın sağlığında tehlike oluşturabilecek kültürel uygulamalar halen devam etmektedir.

Araştırmamızda, kuşaklara göre bebeğin göbek bağının düştükten sonra anlamı olan bir yere 
(cami, okul vb.) gömülmesi açısından önemli bir farklılık bulunmuştur $(\mathrm{p}<0.05)$. Bu uygulama, en fazla Bebek Patlaması Kuşağı'nda görülmektedir. Yapılan bazı çalışmalarda bu uygulamanın devam ettiği belirlenmiştir. ${ }^{9}, 13$ Göbek güdüğüne yapılan diğer geleneksel uygulamalar arasında, göbeğin düşmesi amaciyla kahve tozu sürülmesi, çaput bağlanmas ${ }^{21}$, zeytinyağı sürülmesi, ${ }^{9,13,22}$ alkol, siyah katran, yanmış kül kullanılması ${ }^{2}$ ve yanmış bez bağlanması ${ }^{9}$ da bulunmaktadır.

Tırnak Bakımı; Bebeğin tırnaklarının uzadıkça kesilmesi, kendine zarar vermesini ve enfeksiyon gelişmesini engellemektedir. Araştırmamızda, Bebek Patlaması Kuşağı'ndaki annelerin \%70,00'ının bebeğin tırnağını kesmek için kırkının çıkmasını bekledikleri belirlenmiştir $(p=0,002)$. Yapılan bazı çalışmalar araştırmamızla benzerlik göstermekle birlikte annelerin bebeklerinin tırnaklarını kırkı dolmadan kesmediklerini belirlenmiştir. 2,9,13,22

Kundaklama; Kundaklama, bebeğin sağlığını tehdit eden gelişimsel kalça displazisi açısından önemli bir risk oluşturmaktadır. Araştırmamızda, Bebek Patlaması Kuşağı'ndaki annelerin \%90,00'ının bebeğinin kundakladığ1 belirlenmiştir. Fakat kuşaklar arasında önemli bir farklılık görülmemiştir ( $\mathrm{p}>0,05)$. Bu uygulamanın varlığı yapılan diğer araştırmalarla da kanıtlanmıştır. 2,9,13,21,22

Bebeği Nazardan Koruma ile ilgili Geleneksel Uygulamalar; Türk toplumunda bebeğe zararı olmayan (nazar boncuğu, ayet, cevşen takmak) nazardan koruma uygulamalarının yanı sıra zararı olan uygulamalar (bebeğin gözüne sürme sürülmesi vb.) da yer almaktadır. Araştırmamızda, Bebek Patlaması Kuşağı'ndaki annelerin \%70,00'1 bebeğe zararı olmadığı bilinen nazardan koruyucu uygulamalara başvurmakta olup kuşaklararasında önemli bir farklılık görülmemiştir $(p>0,05)$. Fakat bebeğin gözlerine sürme çekme en fazla \%96,66 ile Bebek Patlaması Kuşağında yapıldı̆̆ı tespit edilmiştir $(\mathrm{p}<0,05)$. Yapılan araştırmalarda, nazar boncuğu, ayet, cevşen, Kur'an takmanın yaygın olarak kullanıldığı gibi, 9,13,21,22 gözlerine sürme sürme ${ }^{21}$, kırk1 çıkana kadar bebeğini adetli kadına göstermeme ${ }^{13}$ gibi uygulamalar da kullanılmaktadır.

\section{Hastalıklardan Koruma ile ilgili Geleneksel Uygulamalar}

Sarılıktan Koruma; Sarılık durumunda, bebeğin derhal bir sağl1k kuruluşuna götürülmesi, nedeninin araştırılması açısından önemlidir. Aksi halde, bebekte hiperbillirubinemi ve kernikterusa yol açabilmektedir. ${ }^{28}$ Araştırmamızda, Z Kuşağ1 annelerinin \%80,00’1 bebeği sarılıktan korumak için sarı tülbent ve kıyafetler kullanmakta olup kuşaklar arasında önemli bir farklılık görülmemiştir. Yapılan bazı çalışmalar, araştırmamızla benzerlik içindedir. 9,13,21,22 Fakat bebekleri sarılık olduğunda bazı annelerin sağlık kuruluşuna götürmedikleri, ${ }^{2,21}$ sarılığın geçmesi amacıyla gelincik suyu ile yıkadıkları, ${ }^{9}$ bebeğin kaşlarını, ${ }^{21}$ topuğunu, kulak arkasını, dil altını jiletle çizdikleri ${ }^{9}$ belirlenmiştir.

Kabızlık, Gaz Sancısı, Pişik Bakımı; Kabızlık, gaz sancısı ve pişikler yeni doğanda sık karşılaşılan sorunlardandır. Araştırmamızda, kabız olan bebeğe zeytinyağı, gaz sancısı olan bebeğe bitki çayları içirme girişimleri açısından kuşaklar arasında farklılık tespit edilmemiştir. Zeytinyağı kullanımı olumlu bir uygulama olarak gösterilmektedir. ${ }^{12}$ Fakat kabız bebeğin anüsüne sabun sürme uygulaması açısından, kuşaklar arasında önemli bir farklılık olmakla birlikte en fazla Bebek Patlaması Kuşağında tespit edilmiştir. Bu uygulama bebeğin hassas cildini tahriş edip bebeğe ağr1 verebileceğinden zararlı bir uygulamadır. Yapılan bir çalışmada, zeytinyağı ve bitki çaylarının kullanımının yaygın olduğu belirlenmiştir.,222 Bazı farmakolojik ajanlar içeren bitki çaylarının, bebek ve küçük çocuklar için güvenilirliği hakkında yeterli bilimsel araştırma bulunmamaktadır. ${ }^{29}$

Perianal dermatit olarak adlandırılan pişik, genellikle bebeğin altının sik ve doğru değiştirilmemesi sonucu oluşmaktadır. Zeytinyağı kullanımı idrarın deriye temasını engellediğinden doğru bir uygulama olarak görülmekte olup, pudra ise bebeğin cildinde tahrişe neden olabileceğinden ve solunum yollarına kaçabileceğinden dolayı önerilmemektedir. ${ }^{12}$ Araştırmamızda, en fazla Bebek Patlaması Kuşağı'ndaki annelerin pişiğe pudra ve zeytinyağ1 uyguladığı belirlenmiştir. Yapılan diğer çalışmaların sonucunda zeytinyağının ${ }^{2,21,22}$ yanı sıra katı yağ $\breve{~}^{21}$, toprağa yatırma ${ }^{22}$, pudra kullanma ${ }^{2,22}$ gibi zararlı olabilecek uygulamalar da mevcuttur.

Pamukçuk Bakımı; Kontamine doğum kanalından geçiş sırasında bulaşan kandida enfeksiyonu pamukçuğa neden olabilmektedir. Ağzın steril su ile irrige edilmesi veya silinmesi pamukçuk bakımına yardımcı olmaktadır. ${ }^{23}$ Araştırmamızda, pamukçuk bakımında kullanılan geleneksel uygulamalar en fazla Z Kuşağı'nda olup, kuşaklar arasında önemli bir farklılık görülmemiştir. Konu ile ilgili yapılan araştırmalarda bu tür uygulamaların halen devam ettiği kanıtlanmıştır. ${ }^{9,21}$

\section{Geniş Aile Olma Durumu ile Geleneksel} Uygulamalara İlişkin Davranışları; Araştırmamızda, annelerin \%41,39'unun geniş aile yapısında olduğu saptanmıştır. Geniş aile yapısı ile geleneksel uygulamaların kullanımı arasında ise önemli bir farklılık saptamamıştır. Yapılan bir çalışmada ise, aile yapısı ile geleneksel yöntem kullanma durumları karşılaştırıldığında, bebeğin 
kundaklanması, tuzlanması ve sarılık olmaması için yapılan uygulamalar, geniş aile yapısına sahip anneler tarafindan daha fazla kullanılmaktadır. ${ }^{2}$

\section{SONUÇ}

Araştırma sonuçlarımız, toplumumuzda bebeğe zararı olmayan geleneksel uygulamaların yanı sıra, zararlı olan geleneksel uygulamaların (bebeğin ilk beslenmesinin geciktirilmesi, tuzlama vb.) doğurganlık çağındaki kuşaklarda da halen devam ettiğini göstermiştir. Geleneksel uygulamalar, çoğunlukla Bebek Patlaması Kuşağı'nda görülmekle birlikte diğer kuşaklarda da varlığını sürdürmektedir. Toplumumuzdaki kültürel uygulamalar, çeşitli sağlık politikaları ile doğum öncesi ve doğum sonrası izlemler yapılmasına, toplumun bebek bakımı konusunda sağlık profesyonelleri tarafindan bilgilendirilmesine rağmen araştırma sonuçlarındaki artış ve azalışlarla halen kendini göstermektedir. $\mathrm{Bu}$ sonuçlar doğrultusundaki önerimiz; özellikle birinci basamak sağlık hizmeti sunumunda anneler ile birebir çalışan ebe ve hemşireler başta olmak üzere, tüm sağlık profesyonelleri, toplumun kültürel özellikleri konusunda anlayış geliştirerek eğitimler verilmelidir. Sağlığın korunması amacı ile ebeler ve hemşireler, holistik ve hümanistik bakım çerçevesinde bilimsel bilgiler ışı̆̆ında sunulmalıdır.

\section{KAYNAKLAR}

1. Türk Dil Kurumu Sözlükleri. https://sozluk.gov.tr/?kelime $=$ Erişim tarihi 10.10.2019.

2. Arisoy A, Canbulat N, Ayhan F. Karaman İlindeki Annelerin $\mathrm{Be} \neg$ beklerinin Bakımında Uyguladıkları Geleneksel Yöntemler. Anadolu Hemşirelik ve Sağlı Bilimleri Dergisi. 2014;17(1):23-31.

3. Tortumluoğlu G. Transkültürel Hemşirelik ve Kültürel Bakım Modeli Örnekleri. C.Ü. Hemşirelik Yüksekokulu Dergisi. 2004;8(2):4756.

4. Christensen SS, Wilson BL, Edelman LS. Can I relate? A review and guide for nurse managers in leading generations. J Nurs Manag. 2018;00:1-7.

5. Carver L, Candela L. Attaining organizational commitment across different generations of nurses. J Nurs Manag. 2008;16(8):984-91.

6. Lower J. Brace Yourself Here Comes Generation Y. Critical care nurse. 2008;28(5):80-7.

7. Kyles D. Managing Your Multigenerational Workforce. Strategic Finance. 2005;87(6):52-5.

8. Adıgüzel O, Batur HZ, Ekşili N. Kuşakların Değişen Yüzü ve Y Kuşağı ile Ortaya Çıkan Yeni Çalışma Tarzı: Mobil Yakalılar. SDÜ
Sosyal Bilimler Enstitüsü Dergisi. 2014;1(19):165-79.

9. Yiğitalp G, Gümüş H. Diyarbakır'da 15-49 Yaş Kadınların Bebek Bakımıyla İlgili Geleneksel Uygulamaları. Türkiye Çocuk Hastalıkları Dergisi. 2017;1-10.

10. Şenses M, Yıldızoğlu İ. Sekiz Ayrı İldeki Kaynana ve Gelinlerin Loğusalık ve Çocuk Bakımında Geleneksel Uygulamaları. Çocuk Forumu Dergisi. 2002;5(2):44-8.

11. Karabulutlu Ö. Kars İlinde Doğum Sonu Dönemde Yenidoğan Bakımına Yönelik Yapılan Geleneksel Uygulamaların Belirlenmesi. DEUHYO ED. 2014;7 (4):295302.

12. Sivri BB, Karataş N. Toplumun Kültürel Yönü: Doğum Sonu Dönemde Anne ve Bebek Bakımına Yönelik Yapılan Geleneksel Uygulamalar ve Dünyadan Örnekler. J Curr Pediatr. 2014;13:183-93.

13. Cetişli NE, Muslu GK, Şen S, Güneri SE, Bolıșık B, Saruhan A. Ege Bölgesinde Doğum Sonu Dönemde Uygulanan Geleneksel Uygulamalar. Uluslararası Hakemli Hemşirelik Araştırmaları Dergisi. 2014;02(01):22-33.

14. Tulay A, Tanrıverdi G. Farklı Kültürlerdeki Kadınlarda Lohusalı $\quad$ Bakımının Karşılaştırılması: Nitel Araştırma. Uluslararası Hakemli Kadın Hastalıkları ve Anne Çocuk Sağlığı Dergisi. 2017;9:1-20.

15. Taplak AŞ, Bayat M. Yenidoğan Bakımında Doğru Bilinen Tehlikeli Geleneksel Uygulamalar. Uluslararası Hakemli Kadın Hastalıkları ve Anne Çocuk Sağlığı Dergisi. 2015;05:67-75.

16. Molu B, Şen TA. Annelerin 0-12 Aylık Bebek Bakımında Başvurdukları Geleneksel Uygulamalar. Uluslararası Hakemli Kadın Hastalıkları ve Anne Çocuk Sağlığı Dergisi. 2016;08:33-45.

17. TC Sağlık Bakanlığı Halk Sağlığı Genel Müdürlüğü Çocuk ve Ergen Sağlığı Dairesi Başkanlığı, TC Sağlık Bakanlığı Anne Sütünün Teşviki ve Bebek Dostu Sağlık Kuruluşları Program1.

https://hsgm.saglik.gov.tr/tr/cocukergen-bpliste/anne-sütünün-teşviki-ve-bebek-dostusağlık-kuruluşları-programı.html Erişim tarihi 10.10.2019.

18. Türk Neonataloji Derneği Term Bebeğin Beslenmesi Rehberi 2018 Güncellemesi. http://www.neonatology.org.tr/wpcontent/uploads/2016/12/term_beslenme_2018. pdf Erişim tarihi 10.10.2019.

19. Çavuşoğlu H. Çocuk Sağlığı Hemşireliği, Ankara, Sistem Ofset Basımevi, 2013. S. 23739.

20. Türkiye Nüfus ve Sağlık Araştırmaları. Ana Rapor; 2018, s. 111, 143. 
21. Biltekin Ö, Boran ÖD, Denkli MD, Yalçınkaya S. Naldöken Sağlık Ocağı Bölgesinde 0-11 Aylık Bebeği Olan Annelerin Doğum Öncesi Dönem ve Bebek Bakımında Geleneksel Uygulamaları. Sürekli Tıp Eğitim Dergisi. 2004;13(5):156-68.

22. Çalışkan Z, Bayat M. Annelerin bebek bakımı uygulamaları ve etkileyen faktörler: Bir Kapadokya örneği. Anadolu Hemşirelik ve Sağlik Bilimleri Dergisi. 2011;14:23-30.

23. Törüner EK, Büyükgönenç L. Çocuk Sağlığ 1 Temel Hemşirelik Yaklaşımları, Ankara, Göktuğ Yayıncılık, 2015. s. 380.

24. Imdad A, Bautista RM, Senen KA, Uy ME, Mantaring JB, Bhutta ZA. Umbilical cord antiseptics for preventing sepsis and death among newborns. Cochrane Database Syst Rev. 2013;(5):CD008635.

25. Samancı N. Yenidoğanın Muayenesi. İçinden Neonatoloji (Eds T Dağoğlu, F Ovalı=:144, 163. İstanbul, Nobel Tip Kitabevi, 2007. s. 144, 163.
26. Ahn Y, Sohn M, Jun Y, Lee E, Lee S. Two methods of cord care in high-risk newborns: their effects on hydration, temperature, $\mathrm{pH}$, and floras of the cord area. J Child Health Care. 2013;19(1):118-29.

27. World Health Organization. WHO Recommendations on Newborn Health. https://www.who.int/maternal_child_adolescen t/documents/newborn-healthrecommendations/en/. Erişim tarihi 10.10.2019.

28. TC Sağlık Bakanlığı Sağlık İstatistikleri Yıllığı Ana Rapor; 2018, s. 25.

29. Türk Neonataloji Derneği Yenidoğan Sarılıklarında Yaklaşım, İzlem ve Tedavi Rehberi. http://www.neonatology.org.tr/wpcontent/uploads/2016/12/sarilik.pdf Erişim tarihi 10.10.2019.

30. Köksal G, Özel HG. Bebek Beslenmesi, Ankara, Hacettepe Üniversitesi Sağlık Bilimleri Fakültesi Beslenme ve Diyetetik Bölümü, 2012. S. 27. 